\title{
Current Cross Border E-Commerce Companies: Developmental Problems And Countermeasures
}

\author{
TzuShan Tseng \\ Ming Chuan University, Taiwan
}

\begin{abstract}
The development of cross border e-commerce industry is one of important global trends. From eMarketer (2019), the global sales of ecommerce in 2018 was 2.5 trillion US dollars and will reach 7.5 trillion US dollars in 2020. In this number - 7.5 trillion US dollars, the cross border e-commerce consumers will occupy $44.6 \%$ of e-commerce's. Due to the quick development, companies will encounter problems by the way. The research purposes of this study was to discuss problems found through Osterwalder and Pigneur's business model canvas analysis and provide suggestions. In this sense, During the time of oneyear industry-academic cooperation program with Company A, the exploratory case study is relying on several sources of data collections through interviews, case analysis, site-visiting observations and secondary data collection (internal and external data) to analyze Company's A cross order e-commerce business model and Taiwan's cross border e-commerce ecosystem. The research subject (Company A) who locate in the vehicles components industry was a Taiwanese SEM and would like to transform into a cross border e-commerce company. The study aimed to explore the cross border e-commerce business model to answer the research question of What is Company A's recent business model canvas ? If Company A would like to transform into cross border e-commerce, what are the problems? What is Taiwan cross border e-commerce ecosystem which Company $A$ is located? The research results and suggestions of this cross border ecommerce company are the following. Firstly, the problem is business opportunities are difficult to catch recently and the amount of each order earned is becoming smaller. The suggestion for this problem is to suggest adapting multiple cross border e-commerce portals operations on budgets and "Software Key activities" for decision making. The second problem is the cost of cross border e-commerce logistic is high. The suggest for this problem is to use Big Data Analysis and artificial intelligence (AI) technology to calculate exact oversea inventories. The third problem is lack of trust. The suggest for this problem is localization strategy, to systematically recruit and train the talents who are familiar with the culture, products and markets. And also The study also has some practical implications for cross-border ecommerce companies.
\end{abstract}

Keywords: Cross Border e-Commerce; Smart Business; Business Model; Localization; Oversea warehouse; Logistics 


\section{RESEARCH BACKGROUND, MOTIVATION, QUESTIONS AND PURPOSE}

The Internet has become an important accelerator for global business. With the population of the Internet and the advancement of information technology, e-commerce has prospered in the global context. Cross border e-Commerce is the new Silk Road in the era. Base on the report of eMarketer (2019), the global e-commerce sales scale was US $\$ 2.5$ trillion in 2018 and will reach US\$7.5 trillion in 2020. In 2020, the amount of consumers in cross border e-commerce will occupy $44.6 \%$ in the whole e-commerce market. The number of third-party cross-border business-to-business (B2B) and business-to-customer (B2C) portals and transaction intermediaries both are increasing. Enormous enterprises start their international venturing on such platforms. For example, Alibaba.com offers hundreds of millions of wholesale products to buyers located in more than 200 countries every year (Alibaba.com, 2019). All of these numbers represent the motivations on researching the fields of cross border e-commerce. Most of the researches on cross border ecommerce researched on customers sides. Fewer researches studied on companies sides. Especially, due to these quick and big development, companies will encounter problems by the way. The research purposes of this paper was to discuss problems found through Osterwalder and Pigneur's business model canvas analysis and provide suggestions. During the time of one-year industry-academic cooperation, interviews, case analysis and external data analysis were used as the research methodology. The research subject (Company A) who locate in the vehicles components industry was a Taiwanese SEM and would like to transform into a cross border ecommerce company.

\section{Research questions:}

1. What is Company A's recent business model canvas?

2. If Company A would like to transform into cross border e-commerce, what are the problems?

3. What is Taiwan cross border e-commerce ecosystem which Company A is located ?

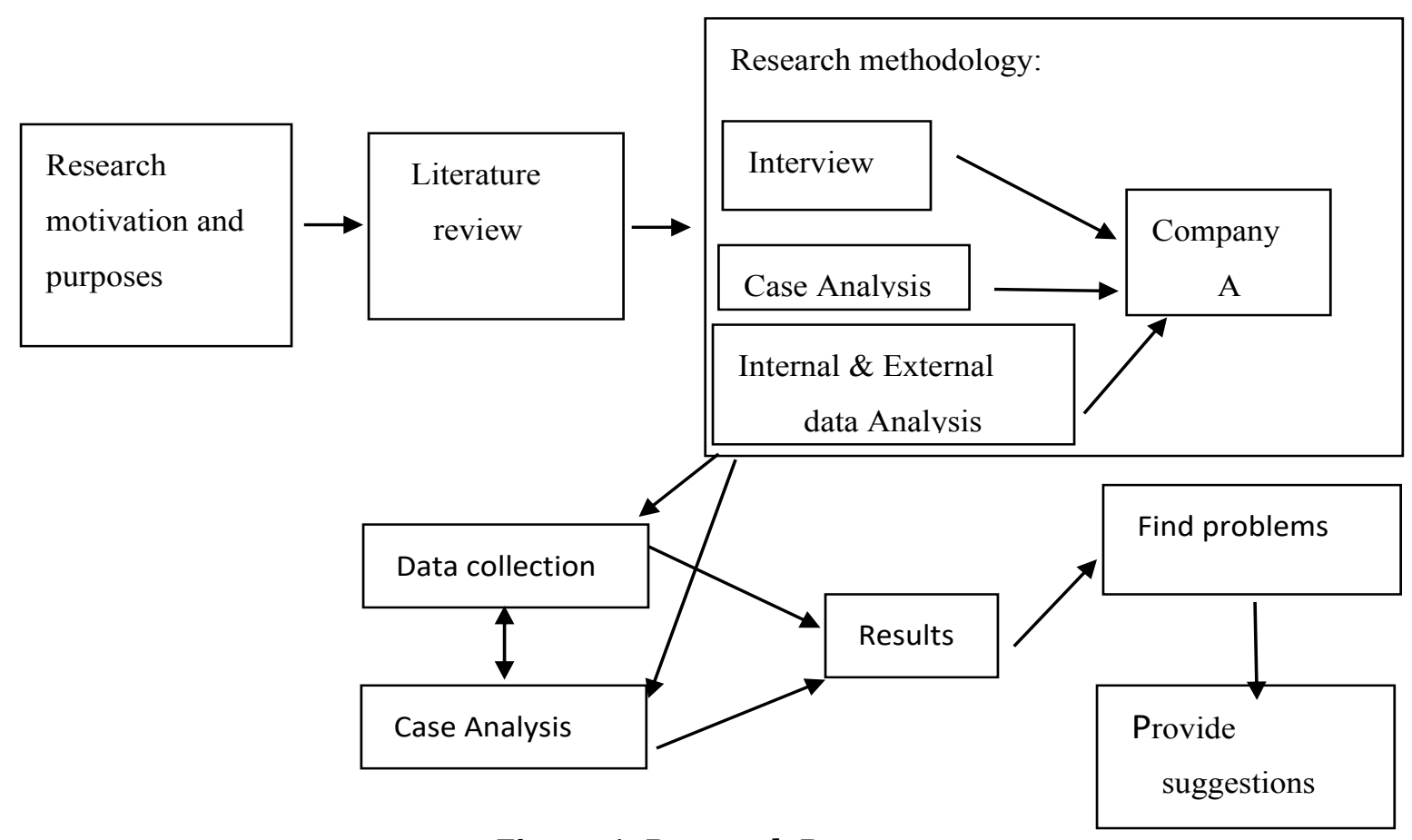

Figure 1: Research Process 
The Research purpose is to provide Company A suggestions.

\section{LITERATURE REVIEW}

The World Trade Organization (2013) defines e-commerce as the sale or purchase of goods or services through computer networks with methods specially designed to place and receive orders. The Internet has become an important accelerator for global business trading. Furthermore, crossborder e-commerce represents different transactions through an e-commerce platform to complete transactions, payments, and settlements, and through cross-border logistics services to complete international business transactions (Li, S \& Wu, Y., 2017). Although cross-border ecommerce has many characteristics of domestic e-commerce, the main difference is that merchants and customers can sell or purchase goods or services via the Internet from anywhere worldwide, which makes cross-border e-commerce more complex than domestic e-commerce (Kawa, A. \& Zdrenka, W., 2016). The number of third-party cross-border business-to-business (B2B) and business-to-customer (B2C) portals and transaction intermediaries are increasing. Enormous enterprises start their international venturing on such platforms. For example, Alibaba.com offers hundreds of millions of wholesale products to buyers located in more than 200 countries every year (Alibaba.com, 2019). The most important and special innovation of these third-party cross-border portals, for example, Alibaba, Amazon and eBay are all building their own "Ecosystem".

\section{Smart Business in Ecosystem}

An "ecosystem" is a community of organisms (businesses and consumers of many types) interacting with one another and the environment (the online platform and the larger off-line physical elements) (Zeng, 2018). The ecosystem was built to link buyers and sellers of goods. As technology advanced, more business functions moved online-including established ones, such as advertising, marketing, logistics, training, finance, and emerging ones, such as affiliate marketing, product recommenders, and social media influencers (Zeng, 2018). Cross border e-commerce companies should adapt to grow in ecosystem and develop strategies to require resources from ecosystem. Moreover, these third-party cross-border portals today are not just an online commerce company. They are data-driven companies. The data network coordinate sellers, marketers, service providers, logistics companies, and manufacturers. Because of new capabilities in network coordination and data intelligence that all these companies put to use. The companies adapting and growing in these ecosystem can be called "Smart business". Smart business is coordinated in an online network and use machine-learning technology to efficiently leverage data in real time. In which most operational decisions are made by machines, allows companies to adapt dynamically and rapidly to change market conditions and customer preferences, gaining competitive advantage over traditional businesses (Zeng, 2018). Conclusively, cross border ecommerce companies should set goal to be Smart businesses which represent the dominant business logic of the future in ecosystem.

\section{Business Model}

There are many definitions of the term business model. Some researches define it as the way a firm generates revenues and believe that it provides guidance on how to generate profits (Gambardella, 2010). Some others also view it from a strategic perspective and think of it as a logical framework to realize an operation (Chesbrough, 2002). 
Tseng, T. (2020) Current Cross Border E-Commerce Companies: Developmental Problems and Countermeasures. Archives of Business Research, 8(5). 263-273.

For this study, we adopt Osterwalder and Pigneur's (2010) definition, in which a business model articulates how the organization earns a profit and thus represents the plan for the strategy to be implemented. They also developed the Business Model Canvas tool and identified nine components of business models. A business model canvas is a summary describing the strategic details needed to get a business (or product) successfully to market. (Osterwalder and Pigneur's, 2010)

The elements of business model canvas are described as the following:

1. Customer segments-Who is going to use this product?

2. Product value propositions-What is this going to do for the customer to make their life/job better?

3. Revenue streams-How will the company make money from this product?

4. Channels-How will the product be sold or distributed?

5. Customer relationships-What is the success and support strategy for new customers?

6. Key partners-What other companies or individuals are part of the development and go-tomarket strategy?

7. Key activities-What must happen internally to release this product?

8. Key resources-What people, materials and budget are required to pull this off?

9. Cost structure-How much will it cost to develop, manufacture, distribute?

Conclusively, a business model can articulate the logic of how an organization creates, delivers, and captures value (Osterwalder and Pigneur's, 2010).

\section{Logistics}

Logistics, which consists of warehousing, sorting, packaging, and distribution, play a significant role in cross-border e-commerce transactions since it links sellers and buyers, and supply and demand. Logistics plays an important role in international business (Marucheck, A. et. al., 2011). An effective logistics strategy can help reduce costs and access foreign markets (Carter, J.R et. al, 1997). Firms must consider flexibility, accuracy, and speed when looking for an appropriate logistics solution for the e-commerce industry ( $\mathrm{Z}$ urek, J., 2015). Nica (2015) states that ecommerce changed purchasing behaviors and thus brought challenges for logistics service providers. He also points out that China's economic expansion increases the demand for logistics services and creates challenges for operators. Cross border e-commerce logistics play an important role in cross border e-commerce companies' competitive advantages.

\section{RESEARCH METHODOLOGY}

The study adopted a case study method. In this sense, During the time of one-year industryacademic cooperation program with Company A, the exploratory case study is relying on several sources of data collections through interviews, case analysis, site-visiting observations and secondary data collection (internal and external data) to analyze Company's A cross order ecommerce business model and Taiwan's cross border e-commerce ecosystem. The research subject (Company A) who locate in the vehicles components industry was a Taiwanese SEM and would like to transform into a cross border e-commerce company. We aim to explore the cross border e-commerce business model to answer the research question of What is Company A's recent business model canvas ? If Company A would like to transform into cross border ecommerce, what are the problems? What is Taiwan cross border e-commerce ecosystem which Company A is located ? And finally, the study would like to provide the suggestions for Company A. 
Due to using a single case study, we adopt a retrospective longitudinal case study approach and trace the analysis back to Company A starting e-commerce businesses in 2011 by asking interviewees for their recollections and by scrutinizing secondary data (company documents and open online resources) on the evolution of the business model. The study follow the processes recommended in the Ketokivi, M.\& Choi, T"s literature to conduct case study research (Ketokivi, M.\& Choi, T., 2014). The designed research methodology is following:



Figure 2: Research Methodology

\section{Case Selection}

A Co., Ltd. is a Taiwanese pace-setting, highly innovative manufacturer and distributor of automotive/ship air conditioning parts, technological diagnostic equipment, and solutions for automotive/ship air-conditioning applications. Company A, founded in 30 years ago with 25 members, is a typically SME in Taiwan with outstanding achievements in global automobile parts market with a lot of national rewards. More than $90 \%$ companies in Taiwan are SMEs but some of them occupy the important position in some industries around the world. Thus, the study selected 
Tseng, T. (2020) Current Cross Border E-Commerce Companies: Developmental Problems and Countermeasures. Archives of Business Research, 8(5). 263-273.

this small but strong company as an outstanding case to explore the research questions. In the past few years, Company A play a leading role in providing customers with high quality racing performance parts, good services, and competitive price. The company's team is not only related to the manufacture, but also to innovation, modification, design and customization as per market feedback and customers' specific requirements. They can manufacture based on customers' samples, logos and designs.

During the time of one-year industry-academic cooperation program with Company A, the exploratory case study is relying on several sources of data collections through interviews, case analysis, site-visiting observations and secondary data collection (internal and external data) to analyze Company's A cross order e-commerce business model and Taiwan's cross border ecommerce ecosystem. The designed research methodology is following:

\section{Data Collection \& Data Analysis}

We rely on four sets of primary and secondary data sources (Ardito, L.; Ferraris, A.; Messeni P. A.; Bresciani, S. \& Del M., 2018) to explore the problems of Company A 's business model canvas and then provide suggestions. The study consulted materials on site and had informal discussions with cross-border e-commerce practitioners and academic researchers in Taiwan. we carried out semistructured interviews with chief executive officer and senior managers of e-commerce in Company A. The interviewees were summarized in the Table 1.

Table 1: Interviewees list: their job position and interview method

\begin{tabular}{|c|c|c|c|}
\hline number & Job position & Interview Method & No. of interviews \\
\hline 1 & CEO & Face to face & 1 \\
\hline 2 & Manager of e-Commerce & Face to face, phone & 2 \\
\hline 3 & Sales representative of e-Commerce & Face to face & 1 \\
\hline 4 & HR manager & Face to face & 2 \\
\hline
\end{tabular}

After collected data via multiple approaches, including semi-structured interviews, informal conversations, observations during multiple site visits, and secondary data from internal documents, the Internet, and industry reports. Field notes, including observation and reflection notes, were taken after each site visit during the one year academic-industry cooperation program. Firstly, the study summarized the case (Company A) description as following Table 2:

Table 2: Case (Company A) Description

\begin{tabular}{|c|c|}
\hline Case Description factors & Case Description factors results \\
\hline Industry position & Automobile/ship parts manufacturer, Exporting \\
\hline Products & Automobile/ship gauge \\
\hline Nationality & Taiwan \\
\hline Business size classification & SME (35 employees) \\
\hline $\begin{array}{c}\text { Years of e-commerce } / \# \text { of years in business } \\
\text { line }\end{array}$ & $8 / 30$ years \\
\hline Types of commercial transaction & B2B, B2C \\
\hline Channels & $\begin{array}{c}\text { Face to face trade show, Local e-commerce } \\
\text { platform, Cross border e-commerce platforms : } \\
\text { Alibaba only (new entrance) }\end{array}$ \\
\hline
\end{tabular}


We adopted qualitative data analysis techniques for this research. The study coded the interview results, internal data and field observations from face to face site visits to identify the factors of Osterwalder and Pigneur's Business model canvas. Then, the study tried to find the developmental problems and provide the solutions for company A.

\section{RESEARCH LIMITATIONS}

There are several limitations in this study. (1). It is a single case (Company A) study who may not have universal applicability. It may examine multiple cases to generate a more instructive meaning. (2). Due to Taiwan's cross-border e-commerce environment is characterized by uncertainty now, the business model or the Taiwan's cross border e-commerce ecosystem may not develop as predicted for other companies and in other contexts.

\section{RESEARCH RESULTS}

This study attempts to answer the research questions. What is Company A's recent business model canvas?

If Company A would like to transform into cross border e-commerce, what are the problems? What is Taiwan cross border e-commerce ecosystem which Company A is located? Then, the Research purpose is to provide Company A suggestions

Firstly, from the interviews and internal documents, the Internet, and industry reports plus field notes, including observation and reflection notes, were taken. The study concluded Taiwan's cross border e-commerce ecosystem which Company A has interactions and influences with the elements inside and outside each other as Figure 3.

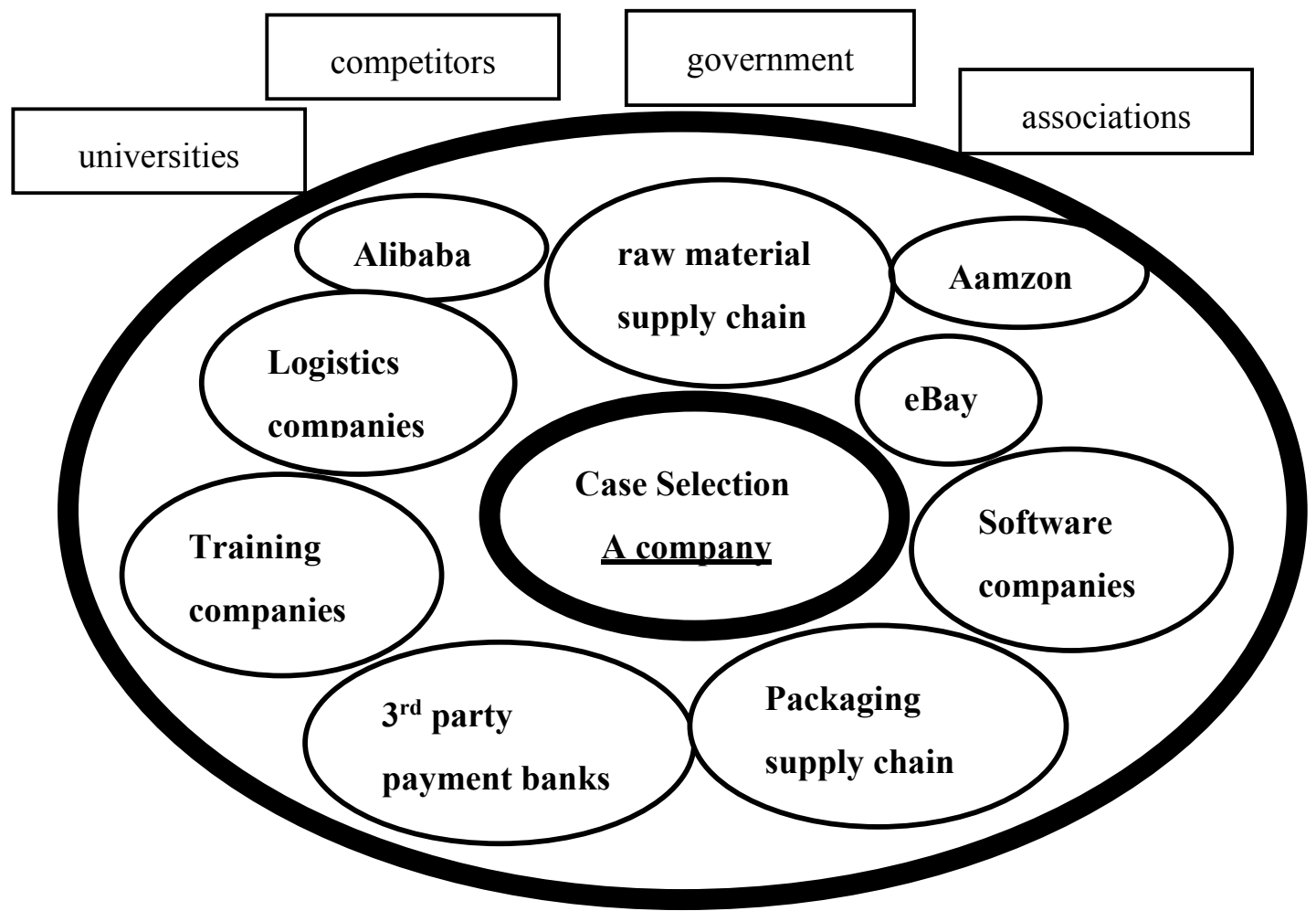

Figure 3: Cross border e-commerce Ecosystem in Taiwan 
Tseng, T. (2020) Current Cross Border E-Commerce Companies: Developmental Problems and Countermeasures. Archives of Business Research, 8(5). 263-273.

Secondly, the study concluded the 9 components of Company A's Osterwalder and Pigneur's business model canvas through the interviews and internal documents, the Internet, and industry reports plus field notes, including observation and reflection notes. The results summarized as Table 3 which included the Company's cross border e-commerce business model canvas and problems found.

Table 3: Interview \& Case analysis results of business model canvas on Company A.

\begin{tabular}{|c|c|c|}
\hline $\begin{array}{l}\text { Factors of Osterwalder and } \\
\text { Pigneur's business model canvas }\end{array}$ & Interview \& Case analysis results & $\begin{array}{l}\text { Problems } \\
\text { found }\end{array}$ \\
\hline Customer Segments & Foreign online shoppers around the world & \\
\hline Value Proposition & Price, Service, Made in Taiwan Product quality & \\
\hline Channels & $\begin{array}{c}\text { Face to face trade show, Local e-commerce platform, } \\
\text { Cross border e-commerce platforms : Alibaba only (new } \\
\text { entrance) }\end{array}$ & $※$ \\
\hline Customer Relationships & $\begin{array}{l}\text { Through Third-party platforms, e-mail, phones by Sales } \\
\text { representatives, Automated services (software) }\end{array}$ & \\
\hline Revenue Streams & Differences between manufacturing cost and selling price & \\
\hline Key resources & Manufacturing know how, 30-years experiences & \\
\hline Key activities & $\begin{array}{l}\text { Face to face trade show, Manufacturing processes \& } \\
\text { innovation }\end{array}$ & $※$ \\
\hline Key partnerships & $\begin{array}{c}\text { Raw material suppliers, Third-party platforms, } \\
\text { Forwarding logistics }\end{array}$ & $※$ \\
\hline Cost structure & $\begin{array}{l}\text { Manufacturing costs, Logistics fees, Overhead costs, } \\
\text { Third-party platforms fees, Marketing fees, }\end{array}$ & $※$ \\
\hline
\end{tabular}

After the problems found in business model canvas of Company A, the suggestions are provided as Table 4.

Table 4: Recent operations with problems found \& suggestions provided

\begin{tabular}{|c|c|c|}
\hline $\begin{array}{c}\text { Factors of Osterwalder and } \\
\text { Pigneur's business model canvas } \\
\text { \& others }\end{array}$ & $\begin{array}{c}\text { Recent operations with } \\
\text { problems found }\end{array}$ & Suggestions \\
\hline Channels & $\begin{array}{c}\text { Face to face trade show, Third- } \\
\text { party platforms : Alibaba only }\end{array}$ & $\begin{array}{c}\text { Adopt multiple platforms } \\
\text { operation: Alibaba, Amazon \& eBay }\end{array}$ \\
\hline Key activities & $\begin{array}{c}\text { Face to face trade show, } \\
\text { Manufacturing processes \& } \\
\text { innovation }\end{array}$ & $\begin{array}{c}\text { Adopt academic-industry programs } \\
\text { to recruit college graduates for } \\
\text { localization strategy }\end{array}$ \\
\hline Key partnerships & $\begin{array}{c}\text { Raw material suppliers, Third- } \\
\text { party platforms, Forwarding } \\
\text { logistics }\end{array}$ & $\begin{array}{c}\text { Adopt oversea warehouses } \\
\text { partners for cross border logistics } \\
\text { \& universities partners for talents }\end{array}$ \\
\hline Cost structure & $\begin{array}{c}\text { Manufacturing costs, Logistics fees, } \\
\text { Overhead costs, } \\
\text { Third-party platforms fees, } \\
\text { Marketing fees, }\end{array}$ & $\begin{array}{c}\text { Adopt more recruiting \& training } \\
\text { cost for talents }\end{array}$ \\
\hline others & No organizational learning & $\begin{array}{c}\text { Adopt training program for cross } \\
\text { border e-commerce employees }\end{array}$ \\
\hline
\end{tabular}




\section{DISCUSSION AND SUGGESTIONS}

In this section, we further clarify the problems findings and discuss the suggestions in the context of the existing literature. After case selection, data collection, data analysis and concluded the results during the time of one-year industry-academic cooperation program with Company A. The following were the discussions and suggestions.

\section{$1^{\text {st }}$ problem}

The business opportunities are difficult to catch recently because of global competitions and the amount of each order earned is becoming smaller.

\section{The suggestion}

is to adapt multiple cross border e-commerce portals on budgets and "Software key activities" for decision making on global market researches and customer preferences, and so on.

\section{2nd problem}

It is the higher cost of logistics. Logistics cost is one item of competitive advantages and also one main concerns of cross border e-commerce buyers.

\section{The suggestion}

is to adapt "group buying" strategy for moving products into oversea warehouse before getting orders. Moreover, use Big Data Analysis and artificial intelligence (AI) technology to calculate exact oversea inventories. And the material of packaging needs simple and light ones.

\section{$3^{\text {rd }}$ problem}

is lack of "Online Trust". Inquiry, negotiation on price and after sale customer service all depend on sales representatives with English communication. The mutual trust is difficult to build upon e-mail, social media APP and long distant telephone. The problems could be cultural differences, different language, and so on.

\section{The suggestion}

for this problem is localization strategy, to systematically recruit and train the talents who are familiar with the culture, products and markets. So before enter the specific market, local market research is necessary. And it should use the third-party money transfer security services. Moreover, face to face Trade Show periodically also help.

Conclusively, this study has contributions to provide suggestions for Company A and other cross border e-companies. And also The study also has some practical implications for cross-border ecommerce companies. First, the analysis of the business models based on the nine components of the business model canvas provides managers with a roadmap to position their own companies. Second, this framework helps policymakers understand how the cross-border e-commerce business ecosystem evolves and the kinds of resources required during the process and thereby allow them to design policies accordingly. Third, our case company also provides a best practice reference to other cross-border e-commerce companies. 
Tseng, T. (2020) Current Cross Border E-Commerce Companies: Developmental Problems and Countermeasures. Archives of Business Research, 8(5). 263-273.

\section{References}

〔1] Alibaba.com. Official Home Website (2019). www.alibaba.com

[2] Anthony, S.D. et.al.(2014). Innovation on the Fly, Harvard Business Review, Volume (Dec., 2014).

〔3] Andrei, H.,\& Simon, R.(2016). Network Effects Aren't Enough. Harvard Business Review, Vol.94, page 64-71.

〔4] Ardito, L.; Ferraris, A.; Messeni Petruzzelli, A.; Bresciani, S. \& Del Giudice, M. (2018). The role of universities in the knowledge management of smart city projects. Technol. Forecast. Soc. Chang. Forth.com.

[5] Chesbrough, H.\& Rosenbloom, R.S. (2002). The role of the business model in capturing value from innovation: Evidence from xerox corporation's technology spin-off companies. Soc. Sci. Electron. Publ. Volume(11), Page 529-555.

[6] D’Ippolito, B.; Miozzo, M.\& Consoli, D (2014). Knowledge systematization, reconfiguration and the organization of firms and industry: The case of design. Res. Policy Volume (43), Page 1334-1352.

[7] dos Reis, J.G.M. (2014). Supply Chain Strategies in the Context of a Commerce Chain (E-CHAIN), Independent. Journal of Management \& Production, Volume(5), n. 2, Page 105-112..

[8] eMarketer Official Web Site (2019). www.eMarketer.com

[9] Gambardella, A. \& McGahan, A.M.(2010). Business model innovation: General purpose technologies and their implications for industry structure. Long Range Plan. Volume(43), Page 262-271.

〔10] Carter, J.R.; Pearson, J.N. \& Li, P. (1997). Logistics barriers to international operations: The case of the People's Republic of China. J. Bus. Logist. Volume (18), Page 129.

[11] Gavet, M. (2014). The CEO of Ozon on Building an e-Commerce Giant in a Cash-Only Economy, Harvard Business Review, Volume (July-August, 2014).

[12] Eisingerich, A.B., \& Kretschmer,T.(2008). In E-Commerce, More Is More, Harvard Business Review, Vol.86 ,2021.

〔13] Hiroshi, M.(2013). Rakuten's CEO on Humanizing E-Commerce, Harvard Business Review, Vol.91, page 47-50.

[14] Huang Z. and Benyoucef, M. (2013). From e-Commerce to Social Commerce: A Close Look at Design Features, Electronic Commerce Research and Applications, 12(4), page 246-259.

[15] Kawa, A. \& Zdrenka, W. (2016). Conception of integrator in cross-border e-commerce. Logforum, Volume (12), Page 63-73.

[16] Ketokivi, M.\& Choi, T. (2014). Renaissance of case research as a scientific method. J. Oper. Manag. Volume (32), Page 232-240.

[17] Li, S \& Wu, Y. (2017). Development Strategy of Cross-border E-commerce in China. DEStech Transactions on Social Science, Education and Human Science. In Proceedings of the MSIE Conference, Jinan, China, 14-15 October 2017; pp. 826-830.

[18] Marshall, W.V., Geoffrey, G.P.,\& Sangeet P.C.(2016). Pipelines Platforms and the New Rules of Strategy, Harvard Business Review, Vol.94, page 54-62.

[19] Marucheck, A.; Greis, N.; Mena, C. \& Cai, L. (2011). Product safety and security in the global supply chain: Issues, challenges and research opportunities. J. Oper. Manag. Volume (29), Page707-720.

[20] McGinn, D. (2014). The Numbers in Jeff Bezos's Head, Harvard Business Review, Volume (Nov., 2014).

[21] Osterwalder, A. \& Pigneur, Y. (2010). Business Model Generation: A Handbook for Visionaries, Game Changers, and Challengers. John Wiley and Sons: New Jersey, NJ, USA.

[22] Nica, E. (2015). Environmentally Sustainable Transport and E-Commerce Logistics. Econ. Manag. Financ. Mark. Volume (10), Page 86-92 
〔23〕Stuart, I. \& McCutcheon, D, Handfield, R.; McLachlin, R.\& Samson, D. (2002). Effective case research in operations management: A process perspective. J. Oper. Manag. Volume(20), Page 419-433.

[24] Wang, Y. \& Schoenherr T. (2018). Supply Chain-Based Business Model Innovation: The Case of a Cross-Border ECommerce Company, Sustainability 2018, 10, 4362

[25] World Trade Organization (2013). E-Commerce in Developing Countries: Opportunities and Challenges for Small and Medium-Sized Enterprises; World Trade Organization (WTO): Geneva, Switzerland, Page 1.

[26]Zeng, M. (2018). "Alibaba and the future of business", Harvard Business Review, Vol.(96) issue(5), page 88-96.

〔27〕Zhu, F., \& Furr, N .(2016). Products to Platforms: Making the Leap, Harvard Business Review, Vol.94, page $72-$ 78.

[28] Z’ urek, J. (2015). E-Commerce Influence on Changes in Logistics Processes. Logforum Volume (11), Page 129 138 